Psychology of Language and Communication 2012, Vol. 16, No. 1

VERSITAOPEN

DOI: $10.2478 / \mathrm{v} 10057-012-0005-9$

\author{
JAN E. OKUNIEWSKI \\ University of Warsaw
}

\title{
POLISH SECONDARY SCHOOL STUDENTS LEARNING GERMAN: MOTIVATION, ORIENTATIONS AND ATTITUDES
}

\begin{abstract}
The study investigates the German language learning motivations of Polish secondary school students. Questionnaire data were collected from 100 students aged 16-18 years. Using the AMOS 18 package, structural equation modeling was run to analyze how language learning goals, attitudes, self-related beliefs, and parental encouragement interact in shaping motivated learning behavior. The results of this study reveal that the important factor which exerts the most influence on motivated learning behavior is an integrative attitude, i.e. openness to and interest in the community using the language, as well as the culture, customs and international status. Another important factor in this model is parental encouragement, as it affects the German language community, learning and instrumental values.

Key words: language learning, second language motivation, language attitudes, social orientations, learning behaviors, German language
\end{abstract}

\section{Introduction}

For several centuries, German served as the most important second language in much of Central and Eastern Europe. The oldest printed material for learning a foreign language in Poland was a little Polish-German phrasebook entitled Eyn kurtze vnd gruntliche Vnderweisung beyder fprachen zu reden vnd zu lesen Polnisch vnd Deutsch. Krotkie ij grvntowne Vkazanye ij navka oboyey mowy mowić ij czisc Polsćye ij Nyemyeckye ('A short and thorough instruction and learning to speak and read both languages Polish and German'), published in the first half of the 16th century ${ }^{1}$. The German language was also a part of the first

Address for correspondence: Jan E. Okuniewski, "Psychology of Language and Communication", Faculty of Psychology, University of Warsaw, Stawki 5/7, 00-183 Warsaw, Poland. E-mail: plc@psych.uw.edu.pl

${ }^{1}$ This book contained no information about the year and place of publication, but historical analyses suggest that it was printed between 1522 and 1524 in Wittenberg (see Pirożyński, 1980; Maier, 2006). 
Polish printed dictionary: Franciszek Mymer's Dictionarius trium linguarum; Latine, Teutonice, et Polonice, potiora vocabula continens, published in 1528 in Cracow by Hieronim Wietor. In 1544 Hieronim Wietor also published a rewritten version of the Eyn kurtze... phrasebook with the title Eyn schone lere mit kortzen synnen begriffen Deutsch und Polnisch beyder sprach zu redenn. Nauka cudna á krotko wypisana ku vczeniu sie Niemcowi Polskiego á Polakowi Niemieckiego ('A beautiful and shortly described learning for a German to learn Polish and for a Pole to learn German'; see Glück, 2002). In 1918, after Poland regained its independence, the obligation was introduced in Polish general schools for students to learn at least one foreign language starting from the 5th grade. At that time, 106,000 students decided to learn German, 77,000 - French, and only ca. 5,000 - English (Blühdorn, 2001).

The role and status of German as a second language only changed after World War II when English gained increasing importance as an international language. In 1990, after the end of communism, foreign language teaching in the Polish education system was thoroughly reformed. The Russian language lost its role of obligatory second language and students could choose between English, French, German and Russian, and, if available, also Spanish and Italian. Currently in the Polish education system, English is the most prevalent foreign language - in the 2009-2010 school year it was studied by $90.4 \%$ of elementary and secondary school (and by $98.0 \%$ of only secondary school) pupils. However, German still retains a significant position among the remaining modern foreign languages offered within compulsory education. In the year 2009-2010, it was studied by $43.3 \%$ of elementary and secondary school pupils, while Russian by $4.3 \%$, French $-3.5 \%$, Spanish $-0.4 \%$, and Italian $-0.2 \%$ (Zarębska, 2011).

The aim of this study was to investigate the socio-psychological motivation factors that influence the taking and learning of German in Polish secondary schools. In particular, the study aimed to find students' motivation orientations toward the language and their attitudes to learning German, to German language communities and their culture.

\section{Concepts and models of language learning motivation}

Motivation is generally considered one of the most important factors influencing the decision to begin learning a second language, persistence with it as well as progress in and effectiveness of the learning process. In theories of second language acquisition the notion of motivation is commonly understood as a complex of factors that include aspirations to achieve certain goals through knowledge of a specific language, readiness to make and sustain an effort to achieve those goals as well as attitudes and beliefs about language acquisition and foreign language communities (Gardner, 1985, 2006; Klein, 1986; Dörnyei, 1998, 2003; Csizér \& Dörnyei, 2005). However, the multi-factorial complexity of 
this notion means that"studying motivation necessarily means slicing off a small piece of the theoretical pie" (MacIntyre, 2002, p. 55). Therefore, the last several decades have seen the emergence of many different conceptions and models of motivation in second (foreign) language acquisition.

The most significant conception which for many years had - and still has - a major influence on research into motivation in second language acquisition is the socio-educational model (Gardner, 1985; see also, for example, Chambers, 1999; Dörnyei, 2005). This model is grounded on the assumption that foreign language learning is different in many respects from learning other fields because language contributes to the social nature of human beings and constitutes an important element of their identity. Here, motivation is treated as a combination of motivational intensity (power), willingness to learn a specific language and learning attitudes (Gardner \& Tremblay, 1994).

The main role in this model is played by the integrativeness and instrumentality factors. The concept of integrativeness "reflects a genuine interest in learning the second language in order to come closer to the other language community" (Gardner, 2001, p. 5). It means not only a willingness to master the language, but also the other community's culture, to understand its various aspects, to get to know people, to make contact with them, as well as a willingness to involve oneself in the functioning of the other language community. This motivational concept also involves the aspiration to achieve not only relative bilingualism, but also relative biculturality (Gardner, 2001). Another motivational factor from the socio-educational model is the concept of instrumentality. In this case the second language and its culture are treated more as a tool helping to achieve personal goals, such as getting an attractive job, enhancing one's chances on the job market or improving one's social status thanks to better education or gaining extra skills. Second language learning is often accompanied by this motivational factor because knowledge of foreign languages is also useful in solving various practical problems, such as gaining access to specialist literature or coping during a visit to a foreign country where not everyone knows other languages (Gardner, MacIntyre, 1995). However, these two second language orientations are not treated as a motivational dichotomy, but as one of many motivational attitudes. The socio-psychological model also includes other motivation molding factors, such as attitudes toward foreign language communities, interest in the culture of those communities, a general interest in foreign languages, social environment effects or anxiety about using the learned foreign language.

Another conception is the self-determination model - a general motivation theory based on the intrinsic and extrinsic motivation dichotomy which is also applied to second language acquisition (Deci, Ryan, 1985; Ryan, Deci, 2000). Intrinsic motivation is the effect of personal experience, aspiration, desire, positive feelings and emotions as well as a sense of autonomy. This type of motivation is considered optimal. Extrinsic motivation is molded by external stimuli, threats, 
pressure, rules of conduct and rewards as well as assimilation of external influences with the personal needs, values and norms of the person learning a foreign language (Deci \& Ryan, 1985).

The third group of factors influencing second language acquisition are variables creating the constructivist model: attitudes toward teaching methods, didactic materials, teachers' modes of action and behavior, situations in the classroom group, and also the interests, personal experiences, aspirations for success or achievements of the persons learning a foreign language (e.g. Crookes, Schmidt, 1991; Oxford, Shearin, 1994; Williams, Burden, 1997).

A model attempting to combine the aforementioned three factor groups that shape motivation in second language acquisition is the process conception of the L2 Motivational Self System (Dörnyei, 2005, 2009; Dörnyei et al., 2006).

However, socio-psychological and classroom/teaching factors largely constitute two separate areas for motivation in foreign language learning. They have a significant impact on learning effectiveness, on account of social attitudes on the one hand and didactic strategies on the other (see Gardner, 2007). Certainly, there is no clear and unambiguous boundary between them; socio-psychological factors are considered in constructivist approaches as well, and learning behaviors are also elements of research and on creating socio-cultural attitudes; what is decisive here is concentration on one or the other sphere of motivational factors.

This study concentrates on socio-psychological questions, but also takes into account behaviors and activities connected with learning a specific language.

\section{Hypothesized model}

In accordance with the principle of structural equation modeling, the process of creating the initial model was based on previous research in the field of L2-learning motivation and educational psychology (Gardner et al., 1999; Csizér \& Dörnyei, 2005; Dörnyei, 2005, 2009; Dörnyei et al., 2006; Gardner, 2007). The hypothesized model is presented in Figure 1. It includes the following factors: social environmental influences, educational goals, attitudes and beliefs concerning language communities and learning behaviors. As adverted above, the relationships in the proposed hypothesized model presented in Figure 1 are based chiefly on the theoretical models reviewed previously as well as the research results from the data and analyses conducted by Dörnyei et al. (see Dörnyei et al., 2006).

On the grounds of Robert Gardner's socio-educational model (1985; 2010), the two most frequently researched concepts of language learning motivation, Integrativeness and Instrumentality, were directly connected with motivational behaviors (e.g. choice of language and intended learning effort) in empirical studies. Attitudes toward language communities arising from psycho-social tradition were also a source of Integrativeness. In addition, it was assumed that Instrumentality was directly and indirectly influenced by Parental Encouragement on account of the 
Figure 1. Schematic representation of the initial hypothesized model

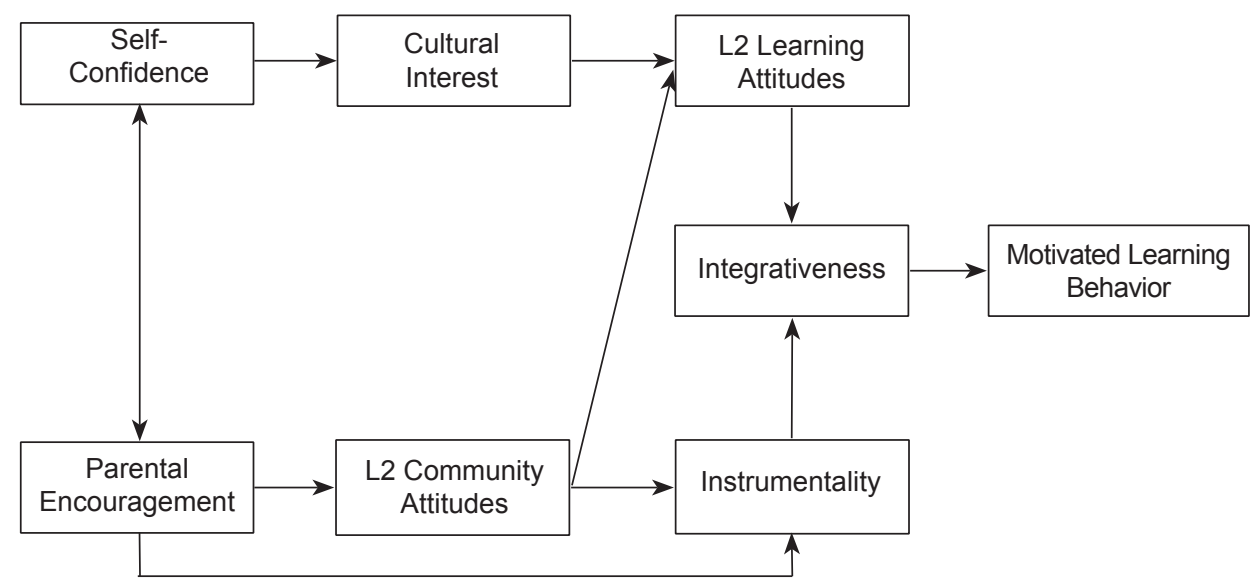

perception of pragmatic, socially constructed benefits, but also linked to Attitudes toward L2 Communities because of practical expectations concerning the second language being dependent on the perceived importance of the L2 found in earlier motivation theories (see Csizér \& Dörnyei, 2005).

In light of past research, Dörnyei et al. (2006) also suggested links between Linguistic Self-Confidence and Parental Encouragement as well as between Linguistic Self-Confidence and Cultural Interest. It was suggested that Linguistic Self-Confidence is influenced by the beliefs of a learner's close environment. The paths of Linguistic Self-Confidence and Attitudes toward L2 Communities were also hypothesized to be mediated through Cultural Interest.

It needs noting that the proposed hypothesized model is based to a considerable degree on English language studies. Because attitudes and beliefs concerning language communities and language status will be different with reference to the German language, it cannot be supposed that the model is independent of the type of language, therefore it would be justified to modify the proposed hypothesized model.

\section{Method}

\section{Participants}

The participants in the survey were 100 students of German (40 boys and 60 girls); 60 of the respondents lived in Warsaw and 40 in Piaseczno, a small town near Warsaw. The students typically started learning German between the age of 11 and 15. They were all between 16 and 18 years old and studied in a general secondary school (two public ones - in Piaseczno and Warsaw - and one private 
Table 1. Demographic data

\begin{tabular}{|c|c|c|c|c|c|}
\hline & & $\begin{array}{c}\text { Public school } \\
\text { students } \\
\text { in Piaseczno }\end{array}$ & $\begin{array}{l}\text { Public school } \\
\text { students } \\
\text { in Warsaw }\end{array}$ & $\begin{array}{c}\text { Private school } \\
\text { students } \\
\text { in Warsaw }\end{array}$ & Total \\
\hline \multicolumn{2}{|l|}{$\mathrm{N}$} & 40 & 38 & 22 & 100 \\
\hline \multicolumn{2}{|l|}{ Mean age } & $17 ; 1$ & $17 ; 6$ & $16 ; 7$ & $17 ; 3$ \\
\hline \multirow{2}{*}{ Gender } & Male $(\mathrm{N})$ & 13 & 18 & 9 & 40 \\
\hline & Female $(\mathrm{N})$ & 27 & 20 & 13 & 60 \\
\hline \multicolumn{2}{|c|}{$\begin{array}{l}\text { Mean time of learning German } \\
\text { (number of semesters) }\end{array}$} & 5.55 & 11.00 & 6.59 & 7.85 \\
\hline
\end{tabular}

one in Warsaw) where it is possible to choose one of several additional second languages (besides English). All of the participants had been previously learning German for approximately 1-8 years. Table 1 summarizes the participants' characteristics.

\section{Materials and procedure}

Quantitative data were collected from the participants with the use of a questionnaire adapted (partially) from (1) the Attitude/Motivation Test Battery (Gardner, 2004) and (2) the Language Orientation Questionnaire (Dornyei \& Clément, 2001). The questionnaire used in this study contained 23 items and a 7-point Likert scale. The statements were intended to cover the following variables:

Integrativeness (3 statements) - interest in learning German in order to interact, meet and socialize with members of German language communities. Example: "Learning German is important to me because it will enable me to better understand and appreciate the German way of life."

Instrumentality (2 statements) - interest in learning German in order to achieve utilitarian benefits such as better jobs or higher social status. Example: "Learning German is important to me because it will be useful in getting a good job."

Cultural interest (2 statements) - attitudes to German culture, cultural products and events. Example: "German-speaking countries have a rich cultural heritage."

Attitudes to German language communities (3 statements) - statements concerning the Austrian, German and Swiss communities' role in today's world. Example: "I would like to know more native German speakers."

Parental encouragement (3 statements) - the extent to which parents encourage their children to learn German. Example:"My parents encourage me to practice my German as much as possible." 
Table 2. The reliability coefficients for the questionnaire scales, means and standard deviations

\begin{tabular}{lcc}
\hline Scales & Cronbach's $\alpha$ & Mean / SD \\
\hline Integrativeness & 0.83 & $4.56 / 1.17$ \\
Instrumentality & 0.74 & $4.21 / 1.13$ \\
Cultural interest & 0.73 & $3.26 / 1.43$ \\
Attitudes to the German language communities & 0.81 & $4.49 / 1.18$ \\
Parental encouragement & 0.77 & $4.04 / 1.42$ \\
Language learning attitudes & 0.71 & $3.92 / 1.29$ \\
Linguistic self-confidence & 0.71 & $3.70 / 1.49$ \\
Motivated learning behavior & 0.83 & $4.88 / 1.30$ \\
\hline
\end{tabular}

Language learning attitudes (3 statements) - the extent to which the secondary school students are willing to learn foreign languages. Example: "I would really like to learn many foreign languages."

Linguistic self-confidence (3 statements) - the level of confidence in German learning and use. Example: "I would feel uneasy speaking German with a native speaker."

Motivated learning behavior (4 statements) - persistence in language study, intended learning effort, enjoyment derived from learning German. Example: "If German were not taught in my school, I would try to take German lessons somewhere else."

The selected schools were first approached with an official letter that provided information about the purpose of the survey. The questionnaire was personally delivered to the schools, where the principals distributed them among German teachers and collected the completed questionnaires. Students participated in the study voluntarily. The questionnaires were filled in during class time and the respondents were given as much time as they needed to complete the questionnaire. Table 2 presents the Cronbach's $\alpha$ reliability coefficients of the scales based on the data collected from the study.

\section{Data analysis}

The accumulated data were prepared for structural equation modeling (SEM) using the AMOS 18 package. The parameter estimation process was based on the method of maximum likelihood (ML). In general, a structural equation model is composed of two parts: the measurement model and the structural model (Kunnan, 1998; Konarski, 2009). At the measurement phase - a variant of confirmatory factor analysis of relationships between latent and measured variables - a certain 
Figure 2. Schematic representation of the final model with standardized estimates

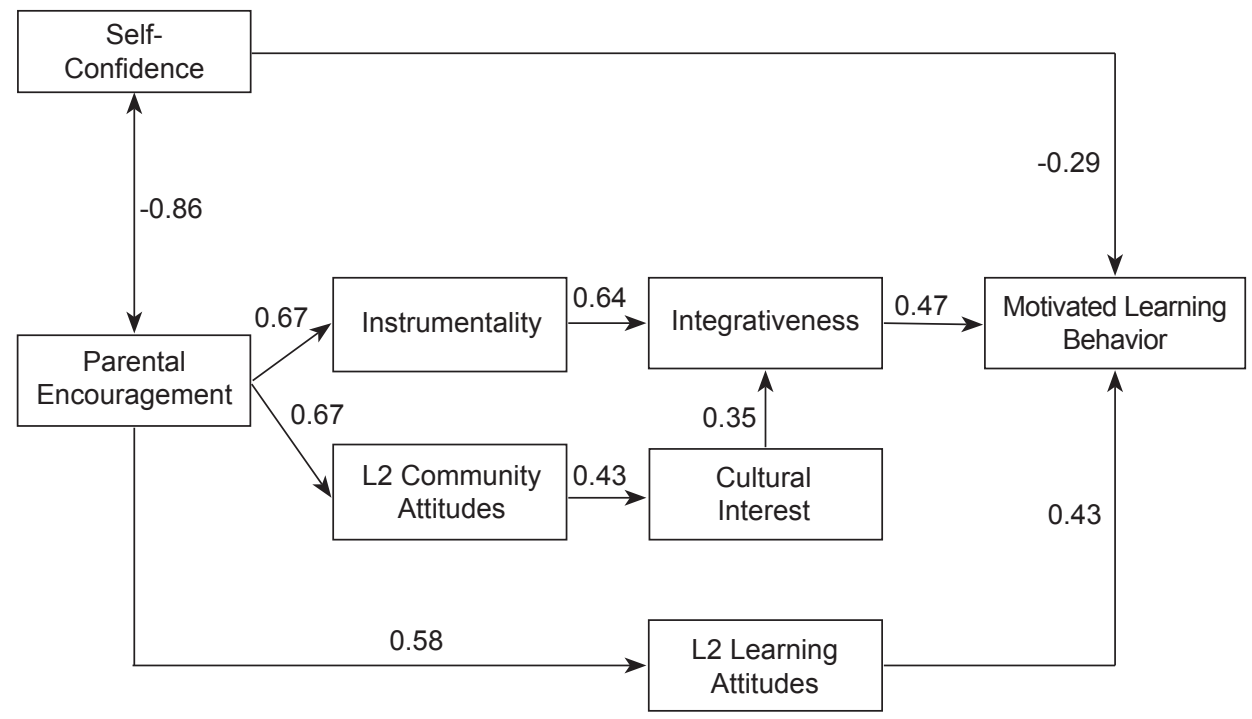

number of modifications were made in order to assure the basic requirements of the model: some observable variables from the questionnaire items were deleted and some intra-scale correlational paths were inserted between the items.

Several criteria were used to evaluate the validity of the final structural model. According to the conventions of structural equation modeling and chisquare statistics, the use of which for such a sample can be debatable, other coefficients were also applied, such as the chi-square to degrees of freedom ratio $\left(\chi^{2} / \mathrm{df}\right)$, factor loadings and residuals, and overall model fit indices. To answer the question whether the parameter values correspond to the input covariance matrix, the following indices were chosen (Konarski, 2009): GFI (Goodness of Fit Index), NFI (Normal Fit Index), CFI (Comparative Fit Index), IFI (Incremental Fit Index), TLI (Tucker-Lewis Index) and RMSEA (Root Mean Square Error of Approximation). The index value $>.90$ is usually considered a satisfactory level of fitness. In the case of the last index, RMSEA, a value below 0.05 is regarded as a very good evaluation.

\section{Results}

The established hypothesized model turned out unsatisfactory. Due to insufficient fit of the initial model (among other things, CFI $=0.922$ but GFI $=0.848$ ), it was modified. Some relationships also proved not to be significant. Therefore, 
Table 3. Selected fit measures for the final model

\begin{tabular}{lcc}
\hline Index & Current level & Accepted level \\
\hline$\chi^{2}$ & $\chi_{(219)}^{2}=206.49 ; p=0.086$ & $p>0.05$ \\
$\chi^{2} / \mathrm{df}$ & 1.147 & $<2$ \\
GFI & 0.935 & $>0.90$ \\
NFI & 0.924 & $>0.90$ \\
CFI & 0.965 & $>0.90$ \\
IFI & 0.967 & $>0.90$ \\
TLI & 0.959 & $>0.90$ \\
RMSEA & 0.039 & $<0.05$ \\
\hline
\end{tabular}

Note. GFI = Goodness of Fit Index; NFI = Normal Fit Index; CFI = Comparative Fit Index; IFI = Incremental Fit Index; TLI = Tucker-Lewis Index; RMSEA = Root Mean Square Error of Approximation

they were removed from the model and a slightly different system of paths was arranged. The final model contains ten significant relationships. Figure 2 shows a schematic presentation of the final model with standardized estimates.

The chi-square to degrees of freedom ratio $(\chi 2 / \mathrm{df})$ is lower than the usually recommended value of <2 (Byrne, 1989; Konarski, 2009). However, it is advisable that the analysis should be based on more than one fit index, therefore these results also rely on alternative fit indices and these all indicate a good fit (see Table 3). It can be determined that the final model creates an appropriate representation of data from this study.

\section{Discussion}

The final model indicates that Motivated Learning Behavior is directly affected by three latent variables: Linguistic Self-Confidence, Integrativeness and Language Learning Attitudes. The direct connection between an integrative variable and a learning behavior variable lends support to the hypothesis on the role of integrativeness in motivational attitudes toward second language learning (Gardner, 2001, 2007; Lamb, 2004; Dörnyei et al., 2006). Because integrative motivation includes openness to German culture and the community using this language, it seems likely that it may be associated more strongly with attaining the ultimate level of achievement than other motivational types. The motivation of school learning may encourage the acquisition of individual elements of the language, but attaining full language competence requires more commitment. Based on the results of this study, it may be assumed that integrative motivation can support such a need. 
Another important factor in the model is Parental Encouragement, because it affects Instrumentality, Attitudes to the German Language Communities and Language Learning Attitudes. This means that the degree to which the family values knowledge of the German language determines the extent of information about language communities and culture and the benefits of language knowledge. The influence of parents, which is exerted through the range of information that learners receive about the language culture and community, indicates that motivation to learn a language is related to factors external to the students. Therefore students' attitudes and motivated behavior should be perceived in the social context that determines the instrumental values related to using a language.

Instrumentality is one of the most popular antecedent motivational attitudes. In this case the second language and its culture are treated more as a tool helping to achieve personal goals. Many studies (e.g. Gardner, 1985, 2006; Dörnyei et al., 2006) suggest that also for relatively young teenage learners the pragmatic benefits related to learning German have an important role in influencing attitudes to the L2. In this model Instrumentality is not directly related to Motivated Learning Behavior, it is affected through Parental Encouragement and plays a role in influencing motivated behavior through the internalization of instrumental values into Integrativeness.

The results of this study suggest that with reference to the German language, Polish secondary school teachers should familiarize themselves with the attitude of the family to their children learning German because they can put more energy into language learning. Unsupportive family attitudes can considerably hinder the process of language acquisition.

One rather surprising element of this model is the negative relationship between Parental Encouragement and Linguistic Self-Confidence as well as the negative effect of Self-Confidence on Motivated Learning Behavior (in comparison with, e.g., Csizér \& Dörnyei, 2005; Dörnyei et al., 2006). Linguistic self-confidence is defined in terms of self-perception of second language competence and a low level of anxiety (MacIntyre et. al., 1998). Based on the results it might be hypothesized that the individual's feelings and convictions related to language competence involve considerable uncertainty about using the second language, above all in direct contacts with native speakers.

The devised model can probably be generalized only for Polish secondary school students learning German, and not for other second language learners. Therefore it would be advisable to carry out research among older learners as well as with reference to L2 self-concept and learning as well as learning experience (Dörnyei, 2009, 2010).

\section{References}

Blühdorn, H. (2001). Lehren und Lernen von Fremdsprachen am Anfang des dritten Jahrtausends - wohin geht der Weg? Retrieved 5.06.2010 from: http://www.ids-mannheim.de/gra/texte/fremdsprachen.pdf 
Byrne, B.M. (1998). Structural equation modeling with LISREL, PRELIS, and SIMPLIS: Basic concepts, applications, and programming. Mahwah, NJ: Lawrence Erlbaum Associates.

Chambers, G.N. (1999). Motivating language learners. Clevedon: Multilingual Matters.

Crookes, G. \& Schmidt, R. (1991). Motivation: Reopening the research agenda. Language Learning, 41, 469-512.

Csizér, K. \& Dörnyei, Z. (2005). The internal structure of language learning motivation and its relationship with language choice and learning effort. The Modern Language fournal, 89, 19-36.

Deci, E.L. \& Ryan, R.M. (1985). Intrinsic motivation and self-determination in human behavior. New York: Plenum.

Deci, E.L. \& Ryan, R.M. (2000). Intrinsic and extrinsic motivations: Classic definitions and new directions. Contemporary Educational Psychology, 25, 54-67.

Deci, E.L. \& Ryan, R.M. (2008). Self-determination theory: A macrotheory of human motivation, development, and health. Canadian Psychology, 4 (3),182185.

Dörnyei, Z. (1998). Motivation in second and foreign language learning. Language Teaching, 78, 117-135

Dörnyei, Z. (2003). Attitudes, orientations, and motivations in language learning: Advances in theory, research, and applications. In Z. Dörnyei (Ed.), Attitudes, orientations, and motivations in language learning (pp. 3-32). Oxford: Blackwell.

Dörnyei, Z. (2005). The psychology of the language learner individual differences in second language acquisition. Mahwah, NJ: Lawrence Erlbaum Associates.

Dörnyei, Z. (2009). The L2 Motivational Self System. In Z. Dörnyei \& E. Ushioda (Eds.), Motivation, language identity and the L2 Self (pp. 9-42). Bristol: Multilingual Matters.

Dörnyei, Z. (2010). Researching motivation: From integrativeness to the ideal L2 self. In S. Hunston \& D. Oakey (Eds.), Introducing applied linguistics: Concepts and skills (pp. 74-83). London: Routledge.

Dornyei, Z. \& Clement, R. (2001). Motivational characteristics of learning different target languages: Results of a nationwide survey. In Z. Dornyei \& R. Schmidt (Eds.), Motivation and second language acquisition (pp. 399-432). Honolulu, HI: University of Hawaii Press.

Dörnyei, Z., Csizér, K., \& Németh, N. (2006). Motivation, language attitudes and globalization: A Hungarian perspective. Clevedon: Multilingual Matters.

Gardner, R.C. (1985). Social psychology and second-language learning: The role of attitudes and motivation. London: Arnold.

Gardner, R.C. (2001). Integrative motivation and second language acquisition. In Z. Dornyei \& R. Schmidt (Eds.), Motivation and second language acquisition (pp. 1-20). Honolulu, HI: University of Hawaii Press. 
Gardner, R.C. (2004). Attitude/Motivation Test Battery: International AMTB research project. Retrieved 5.06.2010 from:

http://publish.uwo.ca/ gardner/docs/englishamtb.pdf

Gardner, R.C. (2006). The socio-educational model of second language acquisition: A research paradigm. In S.H. Foster-Cohen, M. Medved Krajnović, \& J. Mihaljević Djigunović (Eds.), EUROSLA Yearbook. Volume 6(pp. 237-260). Amsterdam, The Netherlands: John Benjamins Publishing.

Gardner, R.C. (2007). Motivation and second language acquisition. Porta Linguarum, 8, 9-20.

Gardner, R.C. (2010). Motivation and second language acquisition. The socioeducational model. New York: Peter Lang.

Gardner, R.C. \& Tremblay, P.F. (1994). On motivation, research agendas, and theoretical frameworks. The Modern Language fournal, 78, 359-368.

Gardner, R.C., Masgoret, A.-M., \& Tremblay, P.F. (1999). Home background characteristics and second language learning. Journal of Language and Social Psychology, 18, 419-437.

Glück, H. (2002). Deutsch als Fremdsprache in Europa vom Mittelalter bis zur Barockzeit. Berlin: de Gruyter.

Konarski, R. (2009). Modele równań strukturalnych. Teoria i praktyka (Structural equation models. Theory and practice). Warszawa: PWN.

Kunnan, A.J. (1998). An introduction to structural equation modelling for language assessment research. Language Testing, 15 (3), 295-332.

Lamb, M. (2004). Integrative motivation in a globalizing world. System, 32, 3-19.

MacIntyre, P.D., Baker, S.C., Clément, R., \& Donovan, L.A. (2002). Sex and age effects on willingness to communicate, anxiety, perceived competence, and L2 motivation among junior high school French immersion students. Language Learning, 52 (3), 537-564.

MacIntyre, P.D., Clément, R., Dörnyei, Z., \& Noels, K.A. (1998). Conceptualizing willingness to communicate in a L2: A situational model of L2 confidence and affiliation. The Modern Language fournal, 82, 545-562.

Maier, I. (2006). Eyn kurtze vnd gruntliche Vnderweisung... Das älteste vollständig überlieferte polnisch-deutsche Gesprächsbüchlein. In H. Glück \& B. Morcinek (Eds.), Ein Franke in Venedig. Das Sprachlehrbuch des Georg von Nürnberg (1424) und seine Folgen (pp. 87-106), Wiesbaden: Harrassowitz Verlag.

Oxford, R. \& Shearin, J. (1994). Language learning motivation: Expanding the theoretical framework. The Modern Language fournal, 78, 12-28.

Pirożyński, J. (1980). Nieznane rozmówki polsko-niemieckie z 1. połowy XVI w. w zbiorach Herzog August Bibliothek w Wolfenbüttel (Unknown PolishGerman phrasebook from the first half of the 16th century in the collection of the Herzog August Library in Wolfenbüttel). Biuletyn Biblioteki Jagiellońskiej, $30(1 / 2), 43-67$. 
Ushioda, E. \& Dörnyei, Z. (2009). Motivation, language identities and the L2 Self: A theoretical overview. In Z. Dörnyei \& E. Ushioda (Eds.), Motivation, language identity and the L2 Self (pp. 1-8). Bristol: Multilingual Matters.

Williams, M. \& Burden, R. (1997). Psychology for language teachers. Cambridge: Cambridge University Press.

Zarębska, J. (2011). Powszechność nauczania języków obcych $w$ roku szkolnym 2009/2010 (The universality of foreign language education in the school year 2009-2010). Warszawa: CODN. Retrieved 9.09.2011 from:

http://bc.ore.edu.pl/dlibra/doccontent?id=200\&dirids=1 